\title{
Evaluation of Different Pre-Slaughter Light Intensities and Fasting Duration in Broilers
}

\section{-Author(s)}

Ramão IB

Nunes RV

Bruno LDG

Tsutsumi CY

Silva WTM

Pozza MSS

Centro de Ciências Agrárias - UNIOESTE campus de Marechal Cândido Rondon Rua Pernambuco, 1777 85.960-000. Marechal Cândido Rondon, Paraná, Brazil.

\section{Mail Adress}

\section{Luís Daniel Giusti Bruno}

Centro de Ciências Agrárias

Universidade Estadual do Oeste do Paraná

Rua Pernambuco, 1777 - Centro

85.960-000. Paraná, Brasil

E-mail: luis.bruno@unioeste.br

\section{-Keywords}

Bacterial counts, carcass yield, feed fasting, light intensity.

\section{acknow ledgements}

The authors appreciate the support from the Agri-Jihad Organization of Yazd province, Iran. The financial support provided by University of Tehran, Iran, is duly acknowledged.

\section{ABSTRACT}

The aim of this study was to determine the effects of different levels of light intensity $(0,5$ or $20 \mathrm{~lx})$ and different pre-slaughter feed fasting duration $(3,6,9,12$ and 15 hours) on the parameters body weight loss, carcass yield, commercial cuts yield, water carcass retention, bacterial counts and breast meat $\mathrm{pH}$. A number of 72 broiler chickens at 45 days of age (Cobb 500 strain) was distributed in three chambers, in a total of 24 broilers per chamber. The results showed that feed fasting significantly influenced $(p<0.05)$ body weight losswhen broilers were submitted to 9 hours of fasting. Broilers kept in the chamber with $0 \mathrm{Ix}$ presented higher body weight loss compared with other light intensities. The results showed an increase in carcass yield $(p<0.05)$ as pre-slaughter feed fasting duration increased, but it did not affect commercial cuts yield or breast meat $\mathrm{pH}(p>0.05)$. The presence of feed in the crop and gizzard did not depend on light intensity, but was affected by pre-slaughter feed fasting duration. Bacterial counts decreased with feed fasting duration $(p<0.05)$.

\section{INTRODUCTION}

Poultry production aims at supplying a highly nutritious product at the least possible cost at the end of the production period. Several factors that may influence the quality and/or price of the final during production have been subject of studies.

One of those factors is the lighting program to which broilers are submitted during the grow-out. According to Rutz \& Bermudez (2004), the adoption of moderate photoperiods may bring several benefits to birds. The level of light intensity (defined as the light flow on a flat surface per lighted area) should be the minimum required to allow birds to identify and to reach the feeders and drinkers, spending the least possible energy in these activities, thereby concentrating their metabolic activity for muscle accretion. High light intensity levels cause intense bird movement, and consequently high energy expenditure. However, it must be mentioned that movement is important during the starter phase of broiler grow-out, as it aids the development of muscles and of the skeleton, preventing future heart and bone conditions (Classen, 1996) as well as cannibalism (North \& Bell, 1990). During subsequent rearing phases, low light intensity improves feed conversion ratio and reduces feed waste. According to Castello et al. (1991), with a light intensity lower than $0.1 \mathrm{Ix}$, it is still possible to see the birds, but they remain inactive; with $1 \mathrm{~lx}$, birds can be easily managed, and they partially develop their activities; and with $5 \mathrm{Ix}$, birds can clearly see and fully develop their activities.

When establishing lighting programs for meat-type poultry, factors like genetics, management practices, housing density, and feed intake 
must be considered. Season and latitude where the poultry houses are located are also important, as these factors affect day duration along the year (Fussel, 2003).

Lighting programs with photoperiods of 23 to 24 hours of light were commonly used in the poultry industry with the aim of maximizing feed intake and weight gain. However, with the development of studies on lighting programs, researchers concluded that better bird performance and welfare could be achieved with moderate photoperiods, which allowed increasing the number of sleeping hours, reducing physiological stress, enhancing the immune response, and possibly improving bone metabolism and leg conditions (Rutz \& Bermudez, 2004).

Several mechanisms have been proposed to explain the positive effects of photoperiods on the physiology of broilers. Reduced growth rate, increased activity levels, metabolic exchanges associated with the dark and production of androgenic hormones have been considered, but up to date none of these factors was shown to be the main responsible for those effects (Rutz \& Bermudez, 2004).

Another frequently studied management practice is pre-slaughter fasting time and its effects on carcass quality. Pre-slaughter fasting is applied to reduce carcass contamination in the processing plant and to improve production efficiency by preventing that the supply of feed that will not be used for muscle accretion a few hours before birds are slaughtered.

Northcutt \& Burr (1998) compared weight loss and carcass yield of broilers slaughtered at 45 or 47 days of age and submitted to $0,6,12$, or 18 hours of fasting and observed that slaughter weight was reduced as fasting time increased. Weight loss per hour after 6 hours of fasting was 0.25 to $0.30 \%$ (45-day-old broilers) and 0.30 to $0.35 \%$ (47-day-old broilers days); however, fasting time did not influence carcass or parts (breast, wings, back, and legs) yields.

Another issue related to fasting time is related to carcass contamination, which may happen when the digestive tract breaks or it is cut during evisceration, or when the digesta is exposed. Several studies were carried out to define fasting durations sufficient to prevent this problem, without affecting bird weight and carcass yield, reaching an average period ranging from 8 to 12 hours (Lyon et al.,1991; Bartov, 1992; Veerkamp, 1992; Rosa, 1999).

Digesta passage rate is influenced by fasting duration, environmental temperature, physical activity levels, and feed intake pattern before feed with drawal.
Fasting reduced feed passage rate through the digestive system in 200 to $300 \%$ (Duke et al., 1969), and it is further decreased as fasting duration increases. May et al. (1988) found that hot environments reduce feed passage rate compared with colder environments (23 ${ }^{\circ} \mathrm{C}$ vs. $13{ }^{\circ} \mathrm{C}$ ). According to Summers \& Leeson (1979), the reduction of bird activity when lights are turned out also delays the emptying of the digestive tract.

Recently, as more de-boned cuts and furtherprocessed products are sold, other issues have called the attention of researchers and other segments of the production chain, such as the effect of fasting on meat quality, particularly on meat $\mathrm{pH}$, tenderness, cooking loss, and chemical composition (Ali et al., 1999; Beraquet,1999; Berri, 2000).

Feed withdrawal changes bird intestinal $\mathrm{pH}$, which may favor the adherence and/or replication of pathogenic microorganisms in segments of the intestines. Hinton et al. (1998), submitting broilers to feed fasting durations of $0,6,12,18$, or 24 hours, did not observe any effect on ceca weight, but the $\mathrm{pH}$ of the cecal content ranged between 6.1 and 6.8 . Those also determined that, when fasting duration increased, total aerobe and enterobacteria counts increased, whereas the counts of bacteria growing in acid medium were reduced.

Stewart et al. (1984) showed breast pH is rapidly reduced from 7.20 to 5.75 in the first 60 minutes after slaughter. According to Khan \& Nakamura (1970), high $\mathrm{pH}$ muscle values are associated with more tender meat. Leitão (2001) mentioned that chicken meat pH values varies according to the carcass parts, and ranges between 5.7 and 5.9 in the breast muscle and 6.4 and 6.7 in the drumstick muscle.

How ever, little is known on the possible relationships among photoperiod, fasting time, carcass yield, carcass contamination, and meat quality. This type of information is extremely useful for the poultry industry, particularly for the end of grow-out and processing. Therefore, this study aimed at evaluating the influence of different lighting intensities and different fasting times on broiler performance, carcass yield, and carcass contamination.

\section{MATERIALS AND METHODS}

The experiment was carried out at Antonio Carlos dos Santos Pessoa experimental farm, located in Linha Guará, Marechal Cândido Rondon, state of Paraná, Brazil, belonging to Universidade Estadual do Oeste do Paraná (UNIOESTE). 
The experimental poultry house was originally divided in 48 pens measuring $1.30 \times 1.35 \mathrm{~m}$ each, in a total area of $1,755 \mathrm{~m}^{2}$. A dark canvas sheet was used to divide the house in three parts, each including 16 pens, in order to control light intensity.

In the experiment, 7,245-day-old Cobb $500^{\circledR}$ broilers were used. Birds were individually identified and weighed, and then randomly distributed into 15 treatments according to a $3 \times 5$ factorial arrangement (3 light intensities $\times 5$ pre-slaughter fasting durations), with 24 birds housed per house division. Average initial individual weight was $3039 \pm 160 \mathrm{~g}$. Birds were offered only water in nipple drinkers.

The light intensities of the house divisions were 0 , 0.5 and 20 lumen $/ \mathrm{m}^{2}$. A digital light meter (model LDL208 Instrutherm) with a Ix scale of 0 to $20,000 \mathrm{Ix}$ in four ranges anda foot-candle scale (Fc) of 0 a 20.000 Fc in four ranges with $0.01-\mathrm{Ix}$ resolution was used to measure light intensity and to adjust them according to the experimental treatments. M easurements were made at a height of $25 \mathrm{~cm}$ from the litter.

Birds started to be slaughtered at 18:30, which was considered as time zero of the experimental period, that is, the beginning of pre-slaughter fasting with no influence of lighting. Twelve birds were slaughtered every three hours, at 21:30; 00:30; 03:30; 06:30 and 09:30h, totaling 15 hours of pre-slaughter fasting.

Light intensity was determined using the light meter at the birds' eye height at the time of catching. After catching, birds were weighed, stunned by neck dislocation, and bled by cutting the jugular vein. After bleeding, carcasses were scalded, de-feathered, eviscerated, and weighed. Carcasses were then placed in a chiller for $30 \mathrm{~min}$ at 0 to $5^{\circ} \mathrm{C}$, in order to prevent muscle shrinkage, after which carcasses were again weighed to determine water absorption. Carcasses remained hanging for 5 min to allow dripping, and then cut up. Carcass yield was determined as carcass weight after chilling and dripping relative to live weight at slaughter. Breast, wings, thighs and drumsticks were weighed to determine their yields relative to carcass weight. Crops and gizzards were examined at the time of evisceration to check for the presence of feed or litter.

Digesta was collected during slaughter by scraping the duodenum, and submitted to the microbiology laboratory of Universidade Estadual do Oeste do Paraná for bacterial count.

$\mathrm{M}$ eat $\mathrm{pH}$, as a meat quality parameter, was measured by collecting $10 \mathrm{~g}$ of breast meat, which were ground in a food processor with $90 \mathrm{ml}$ of distilled water. The $\mathrm{pH}$ was measured using a pHmeter(TEC-2, Technal) after 10 minutes.

The following parameters were analyzed: body weight, body weight loss, chilled carcass yield, carcass yield after dripping, cuts yield (breast, wings, drumstick and thigh), breast meat $\mathrm{pH}$ and digesta bacterial counts.

The obtained data were submitted to statistical analysis using SAEG software package, and means were compared by the test of Student-Newman-Keuls (SNK) at 5\% probability level. Regression analysis and the Chi-Square test $\left(x^{2}\right)$ were applied to evaluate the influence of fasting duration and light intensity on the presence of feed in the crop and gizzard.

\section{RESULTS AND DISCUSSION}

The results presented in Table 1 show a significant interaction $(p<0.05)$ between light intensity and pre-slaughter fasting duration. As expected, birds increasingly lost weight as fasting duration increased, which is consistent with the findings of Northcutt \&Burr (1998). Birds maintained in the dark and submitted to 15 hours of fasting lost more body weight; however, there was no difference at $5 \%$ probability level between birds maintained at the same light density. Birds submitted to the same fasting duration lost the least body weight when maintained at $5 \mathrm{Ix}$. Table 1 shows the results of body weight loss according to fasting duration and light intensity. The equations, obtained by analysis of regression, allow predicting weight loss as a function of fasting duration and light intensity.

Broilers maintained in the dark lost more weight than those maintained at $5 \mathrm{Ix}$ and $20 \mathrm{Ix}$. However, this

Table 1 - Body w eight loss $(\mathrm{g})$ of broilers submitted to different fasting durations as a function of light intensity.

\begin{tabular}{|c|c|c|c|c|c|c|}
\hline \multicolumn{6}{|c|}{ Fasting duration (hours) } & \multirow{2}{*}{ CV } \\
\hline Light intensity (lux) & 3 & 6 & 9 & 12 & 15 & \\
\hline 0 & $28.75 \mathrm{a}$ & $66.25 \mathrm{a}$ & $83.75 \mathrm{a}$ & $87.50 \mathrm{a}$ & $95.00 \mathrm{a}$ & \multirow{3}{*}{43.88} \\
\hline 5 & $25.00 \mathrm{a}$ & $53.33 \mathrm{a}$ & $76.25 b$ & $67.50 \mathrm{a}$ & $83.33 \mathrm{a}$ & \\
\hline 20 & 26.67 a & $50.00 \mathrm{a}$ & $78.75 b$ & $67.50 \mathrm{a}$ & $87.50 \mathrm{a}$ & \\
\hline Light intensity (lux) & \multicolumn{5}{|c|}{ Equations } & $\mathbf{R}^{2}$ \\
\hline 0 & \multicolumn{5}{|c|}{$y=-0.01992+0.01081 *$ hour $-0.00051155 *$ hour $^{2}$} & $0.45^{* *}$ \\
\hline 5 & \multicolumn{5}{|c|}{$y=-0.00148+0.00257 *$ hour $-0.00008063 *$ hour $^{2}$} & $0.23^{*}$ \\
\hline 20 & \multicolumn{5}{|c|}{$y=0.00109+0.00180 *$ hour $-0.00001554 *$ hour $^{2}$} & $0.39 * *$ \\
\hline
\end{tabular}

M eans follow ed by the same letter in the same column are not statistically different by the SNK test at $5 \%$ probability level.* and $* *$ indicate significant difference of Pearson's coefficients at 5 and $1 \%$ levels, respectively. 
difference was statistically significant only when birds were submitted to nine hours of fasting.

According to the studies of Wabeck (1972); Chen et al. (1983); Rasmussen \& Mast (1989); Lyon et al. (1991); and M endes (2001), body weight loss increases with fasting duration, which is physiologically expected and shown in the present experiment. According to Denadai et al. (2001), this is due to the lower feed content in the intestinal tract, as also verified in the present study. Duke et al. (1997) mentions that, in addition to lower digesta content, weight loss is also due to muscle dehydration, which was not detected in the present experiment as no influence of fasting duration on carcass water absorption was detected.

Lyon et al. (1991), evaluating the effect of fasting durations of $0,8,16$, and 24 hours on broiler weight loss, observed that it linearly increased with fasting duration. The linear body weight loss as a function of fasting time was also detected by Wabeck (1972), who determined that weight loss of broilers submitted to 24 hours of fasting was the double of those fasted for 12 hours.

Carcass yield parameters (post-slaughter carcass yield - PSCY, and post-chilling carcass yield - PCCY), shown in Table 2, were directly influenced by fasting duration $(p<0.05)$, but were not affected by light intensity during fasting ( $p>0.05)$. There was an increase in the values of these parameters as fasting duration increased. PSCY was low when birds were submitted to zero, three, and six hours of fasting, but significantly increased after nine hours of fasting $(p<0.05)$. Carcass yields after chilling and after dripping were lowest when birds were not submitted to fasting, and linearly increased with fasting duration $(p<0.05)$.

These results are consistent with the findings of Lyon et al. (1991), Baião et al. (1992) and Denadai et al. (2001), who showed that broilers not submitted to fasting presented the lowest carcass yield. On the other hand, Rasmussen \& M ast (1989) did not find any carcass yield differences when comparing $0,6,12,18$ hours of feed fasting ( $p>0.05)$.

Table 2 presents the equations to determine carcass yields as a function of feed fasting duration, with hour indicating how long the birds were fasted.

Water absorption by the carcass and cuts yield (Table 3) were not influenced by fasting duration or light intensity $(p>0.05)$. These results agree with those of Benibo \& Farr (1985), who also did not observe any effect of fasting duration on carcass water absorption.

Table 3 shows that breast, wings, drumstick, and thigh yields were not influenced by fasting duration or light intensity $(p>0.05)$.
The results presented in Table 4 show that the presence of feed in the digesta and the crop do not depend on light intensity.

Table 2 - Carcass yields as a function of fasting duration.

\begin{tabular}{cccc}
\hline \multirow{2}{*}{$\begin{array}{c}\text { Fasting duration } \\
\text { (hours) }\end{array}$} & \multicolumn{3}{c}{ Carcass yields (\%) } \\
\cline { 2 - 4 } & PSCY & PCCY & PDCY \\
\hline 0 & 71.21 & 72.78 & 71.66 \\
3 & 72.09 & 73.27 & 72.55 \\
6 & 72.01 & 73.66 & 72.78 \\
9 & 73.89 & 75.14 & 74.44 \\
12 & 74.37 & 75.59 & 74.97 \\
15 & 74.30 & 75.63 & 75.19 \\
CV (\%) & 2.690 & 2.920 & 2.860 \\
\hline Prob. & 0.01 & 0.03 & 0.01 \\
\hline Carcass yield & \multicolumn{3}{c}{ Equations $\mathbf{R}^{2}$} \\
\hline PSCY & $\mathrm{y}=71.334+0.22061 *$ hour & $0.19 * *$ \\
PCCY & $\mathrm{y}=72.70058+0.21575 *$ hour & $0.16 * *$ \\
PDCY & $\mathrm{y}=71.78425+0.24269 *$ hour & $0.20 * *$ \\
\hline
\end{tabular}

PSCY: post-slaughter carcass yield; PCCY: post-chilling carcass yield; PDCY: post-dripping carcass yield. * and $* *$ indicate significance at 5 and $1 \%$ levels, respectively, by Pearson's coefficients.

Table 3 - Water absorption and cuts yield as a function of fasting duration.

\begin{tabular}{cccccc}
\hline \multirow{2}{*}{$\begin{array}{c}\text { Fasting duration } \\
\text { (hours) }\end{array}$} & \multicolumn{5}{c}{ Carcass yield (\%) } \\
\cline { 2 - 6 } & WA & BY & WY & DY & TY \\
\hline 0 & 1.100 & 35.37 & 11.42 & 14.79 & 17.95 \\
3 & 0.631 & 34.36 & 11.26 & 14.36 & 17.53 \\
6 & 1.070 & 34.91 & 11.52 & 14.99 & 17.17 \\
9 & 0.735 & 35.29 & 11.47 & 14.70 & 17.76 \\
12 & 0.790 & 36.03 & 10.98 & 14.48 & 17.65 \\
15 & 1.189 & 36.07 & 11.45 & 14.62 & 17.82 \\
Cv. & 63.79 & 5.55 & 4.65 & 8.51 & 9.00 \\
Prob. & ns & ns & ns & ns & ns \\
\hline
\end{tabular}

WA: water absorption; BY: breast yield; WY: wings yield; DY: drumstick yield; TY: thigh yield.

Table 4 - Chi-square values for the presence of feed related to light intensity in broilers.

\begin{tabular}{lcc}
\hline Chi-square & & \\
Presence of feedxlight intensity & Obtained $\mathrm{x}^{2}$ & Calculated $\mathrm{x}^{2}$ \\
\hline Crop & 5.99 & 4.25 \\
Gizzard & 9.49 & 4.03 \\
\hline
\end{tabular}

On the other hand, fasting duration directly influenced the presence of feed in the crop and gizzard as calculated Chi-square values were statistically higher than the obtained value (Table 5).

The results of duodenum bacterial counts (Table 6) obtained in the present study showed that there is an interaction of bacterial count with fasting duration $(p<0.05)$, but not with light intensity $(p>0.05)$. Bacterial counts in the duodenum are reduced as fasting duration increases. The highest bacterial counts 
were obtained in the periods of 0,3 and 6 hours of fasting, and were significantly reduced $(p<0.05)$ after this period.

Table 5 - Chi-square values for the presence of feed related to fasting duration in broilers.

\begin{tabular}{lcc}
\hline Chi-square & & \\
Presence of feed $\boldsymbol{X}$ fasting duration & Obtained $\boldsymbol{X}^{2}$ & Calculated $\boldsymbol{X}^{2}$ \\
\hline Crop & 9.49 & 34.28 \\
Gizzard & 15.51 & 17.14 \\
\hline
\end{tabular}

Table 6 - Duodenum bacterial counts and breastpH as a function of fasting duration.

\begin{tabular}{ccc}
\hline Fasting duration (hours) & Bac (CFU) & pH \\
\hline 0 & 8.750 & 6.70 \\
3 & 8.615 & 6.80 \\
6 & 9.115 & 6.72 \\
9 & 8.343 & 6.47 \\
12 & 6.717 & 6.72 \\
15 & 6.076 & 6.64 \\
CV (\%) & 18.33 & 2.51 \\
Prob. & 0.02 & ns \\
\hline
\end{tabular}

Bac: bacterial count; $\mathrm{pH}$ : breast $\mathrm{pH}$; CFU: colony-forming units.

Breast $\mathrm{pH}$ values measured after slaughter were not influenced $(p>0.05)$ by fasting duration or light intensity (Table 6), and the low est value was obtained when broilers were fasted for 9 hours. Consistent with these results, Kotula \& Wang (1994), when comparing fasting durations of $0,3,6,12,18,24$ and 36 hours, found that when pre-slaughter fasting increased from 0 to 36 hours, breast pH decreased from 6.97 to 6.36, indic the influence of fasting duration on meat quality. Stewart et al. (1984) verified that breast $\mathrm{pH}$ rapidly falls from 7.20 to 5.75 afterrigor mortis, during the first 30 to 60 minutes after slaughter. According to Khan $\&$ Nakamura (1970), high $\mathrm{pH}$ values in the muscle are associated to greater meat tenderness.

The experimental conditions of the present study are evidently different from those observed in the field, but provide indications of the influence of the association of light intensity with pre-slaughter fasting duration on broilers. Under commercial conditions, zero light intensity could be very useful, particularly in relation to the stress to which birds are submitted due to age, housing density, catching, etc. Moreover, it could benefit the final consumers by providing better meat quality. How ever, further studies on management practices that could allow these conditions to increase even further the efficiency of the production chain.

\section{CONCLUSIONS}

The use of different light intensities, associated to different pre-slaughter feed fasting periods, influenced the evaluated parameters; however, the interaction among these factors was not always present. Carcass parameters were more affected by fasting periods, whereas light intensity affected weight loss before slaughter.

\section{REFERENCES}

Bartov I. Effect of feed withdrawal on yield, fat content, and fatty acid composition of various tissues in broilers. Proceedings of the 19th World'sPoultry Congress; 1992 Sep 20-24; Amsterdam. Holanda. v.3, p.20-24

Beraquet NJ. Influência de fatores ante e post morten na qualidade da carne de aves. RevistaBrasileira de Ciência Avícola 1999; 1(3):155-166.

Berri C. Variability of sensory and processing qualities of poultry meat. World's Poultry Science Journal 2000; 56(3):209-224.

Castello JA, Franco F, Garcia et al. Manejo de lospollos. In: Costéllo Llabet JA. Producción de carne de pollo. Barcelona: Tecnograf; 1991. cap.6, p.112-116. 1991.

Classen HL. Principios sobre el manejo de luz em pollos de engorda. Avicultura Professional 1996; 14(2):22-27.

Chen TC, Schultz CD, Reece RN, Lott BD, McNaughton JL. The effect of extended holding time, temperature, and dietary energy on yields of broilers. Poutry Science 1983; 62:1566-1571.

Denadai JC, M endes AA, Garcia RG, Almeida ICL, M oreira J, Takita TS, Pavan $A C$, Garcia EA. Efeito do tempo de jejum pré-abate sobre o rendimento de carcaça e a qualidade da carne de peito de frangos de corte. Anais da $38^{\circ}$ Reunião Anual da Sociedade Brasileira de Zootecnia; 2001; Piracicaba, São Paulo. Brasil: SBZ; 2001. p.394-395.

Duke GE, Dziuk HE, Hawkins L. Gastrointestinal transit-times in normal and bluecomb diseases turkeys. Poultry Science 1969; 49:835-842.

Duke GE, Maureen B, Noll S. Optimum duration of feed and water removal prior to processing in order to reduce the potential for fecal contamination in turkeys. Poultry Science 1997; 76 (3):516-522.

Fussel LW, Diplomate MAM, Rossi A. et al. Lighting programs and Cobb 500 broiler performance. Technical Focus 2003; 1:1-4.

Hinton Jr A, Buhr RJ, Ingran KD. Effect of feed withdrawal on bacterial flora, $\mathrm{pH}$, and weights of the ceca of chickens. Proceedings of the 87th Poultry Science Association Annual Meeting Abstracts; 1998; Denver, Colorado. USA. 90p.

Khan AW, Nakamura R. Effect of pre- and postmorten glycolysis on poultry tendernes. Journal of Food Science 1970; 35:266-267.

Kotula KL, Wang Y. Characterization of broiler meat quality factors as influenced by feed withdrawal time. Journal of Applied Poultry Research 1994; 3(2):103-110.

Leitão MFF. Qualidade e segurança alimentar em produtos avícolas. Anais da Confererência Apinco de Ciência e Tecnologia Avícolas; 2001; Campinas, São Paulo. Brasil: FACTA; 2001. p.181-190. 
Lyon CE, Papa CM, Wilson Junior RL. Effect of feed withdrawal on yields, muscle $\mathrm{pH}$, and texture of broiler breast meat. Poultry Science 1991; 70: 1020-1025.

M ay JD, Branton SL, Deaton JW. et al. Effect of environmental temperature and feed regimen on quantity of digestive tract contents of broilers. Poultry Science 1988; 67:64-71.

M eddis R. On the function of sleep. Animal Behaviour 1975; 23:679-691.

Mendes AA. Rendimento e Qualidade da Carcaça de Frangos de Corte. Anais da Conferência Apinco de Ciência e Tecnologia Avícolas; 2001; Campinas, São Paulo. Brasil: FACTA; 2001. p.79-99.

Northcutt JK, Burr RJ. Influence of feed withdrawal on slaughter weight and processing yield of broilers. Proceedings of the 19 Annual Meeting Abstracts; 1998; Phyladelphia, Pensilvânia. USA. p.152.

North M O, Bell D. Lighting management. In: North M O, Bell D. Commercial chicken production manual. 4 ed. New york: International Thonson Publishing; 1990.

Rasmussen AL, Mast MG. Effect of feed withdrawal on composition and quality of meat. Poultry Science 1989; 68:1109-1113.

Ribeiro Junior JI. Análises estatísticas no SAEG. Viçosa: UFV; 2001. 301p.

Rosa PS. Restrição Alimentar. Avicultura Industrial 1999; 1073:14-18.

Rutz F, Bermudez VL. Fundamentos de um programa de luz para frangos de corte. In: M endes AA, Naas IA, M acari M, editores. Produção de frangos de corte. Campinas: FACTA; 2004. p.157-168.

Stewart MK, Fletcher DL, Hamm D. et al. The effect of hot boning broiler breast meat muscle on postmorten pH decline. Poultry Science 1984; $63: 2181-2186$.

Summers JP, Leeson S. Comparison of feed withdrawal time and passage of gut contents in broiler chickens held in crates or litter pens. Canadian Journal of Animal Science 1979; 59:63-66.

Wabeck CJ. Feed and water withdrawal time relationship to processing yield and potential fecal contamination of broilers. Poultry Science 1972; 51:1119-1121.

Veerkamp $\mathrm{CH}$. Future research for pre-slaughter handling, stunning and related processes. Proceedings of the $19^{\text {th }}$ World's Poultry Congress; 1992 Set 20-24; Amesterdam. Holanda. p.352-359. 